JMTM 30,4

\title{
Editorial
}

650

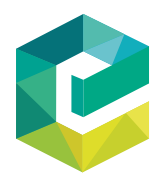

Journal of Manufacturing Technology Management Vol. 30 No. 4,2019 pp. $650-665$

(C) Emerald Publishing Limited 1741-038X

DOI 10.1108/JMTM-06-2019-357

\section{Successful publishing in the journal of manufacturing technology management: a download-based analysis for determining impact}

\subsection{Academic publishing}

An important aspect of academia is to conduct research and to share the results of this research with others in the field. This allows scholars to learn from each other and because of this it allows for progress to be made. An important mechanism to share results of research is through publication of those results. Consequently, publishing is a major part of what scholars do. For example, in the USA many universities have strict standards in terms of the number and type of publications that are required of faculty members to earn promotions, tenure or merit awards.

It comes, therefore, as little surprise that the issue of how to get published is broadly covered in many disciplines and from a variety of angles. For instance, books such as Writing a Successful Thesis or Dissertation: Tips and Strategies for Students in the Social and Behavioral Sciences (Lunenburg and Irby, 2008), The Dissertation Warrior: The Ultimate Guide to Being the Kind of Person Who Finishes a Doctoral Dissertation or Thesis (White, 2017) and Completing Your Qualitative Dissertation: A Road Map from Beginning to End (Bloomberg and Volpe, 2019) are aimed at $\mathrm{PhD}$ students and help them with their beginning stage of writing, that is, the dissertation. Publications such as Writing Your Journal Article in Twelve Weeks: A Guide to Academic Publishing Success (Belcher, 2009), Write It Up: Practical Strategies for Writing and Publishing Journal Articles (Silvia, 2015 and How to Write and Publish a Scientific Paper: The Step by Step Guide (Claudio and Boles, 2016) provide academics with help to publish in a scientific journal. There are also sources that are specific to certain academic disciplines such as Gutman (2017) for healthcare journals and even for specific journals, for instance Te'eni et al. (2015) provide advice on how to get published in the European Journal of Information Systems.

What plays an important part in the ability of publishing successfully in scientific journals is the ability of authors to handle the peer-review process. While exceptions occur, such as blacklisted journals, see for example Cabells which creates such as list at www2. cabells.com/journals, most respectable journals follow a single- or double-blind review process. This type of review process is by no means without drawbacks and has been criticized for decades. For instance the issue of bias has been raised (Sigelman and Whicker, 1987) and that too many good ideas do not make it through the review process (Saunders, 2005a). Note for example how scientific papers that were rejected ended up leading to a Nobel prize (MacDonald, 2016) or otherwise renowned work has been rejected (Gans and Shepherd, 1994). This has led, among other things, to advice for editors (Saunders, 2005b; Brown, 2013) but also calls for a different type of process (Weber, 1999) and different methods to reward reviewers (Kachewar and Sankaye, 2013). Despite these concerns and ideas for improvements, the single- or double-blind review process has remained a standard for determining article quality. While engaged in this review process, it can often be challenging for authors to improve their submission while dealing with the comments of multiple reviewers. For instance, Dalton et al. (2016) note that about 50 percent of the papers that initially receive a revision decision end up still rejected in later rounds. A number of articles have appeared related to the review process. Some articles, often written as editorials, provide guidance to authors with the review process and these lessons are often valid for other journals as well. For instance, Chrisman et al. (2017) is an editorial for the peer-reviewed Family Business Review journal and helps authors to gain insight into the 
perspective of editors and reviewers. Similarly, Liu (2014) is an editorial for Management and Organization Review and provides advice on how to respond to reviewer comments. Other sources such as Dalton et al. (2016) provide a more general rather than a specific editorial scope.

Overall, what the above shows is that a lot of advice is available for authors on how to get published but it remains a question whether this has led to improved publications. It also remains a question how to look at, and determine the quality of, publications. The next section will delve deeper into the quality of scientific publications.

\section{2. "Quality" and impact of scientific journal articles}

As explained in the previous section, many universities require of faculty that they publish in scientific journals. Larsen and von Ins (2010) showed how the number of articles that are published continues to grow and the same applies to the available number of outlets. They discuss growth from about 60,000 journals in existence between 1650 and 1950 but that by 2002 there were over 905,000 (Larsen and von Ins, 2010). A concern then is whether the pressure to publish and the availability of so many outlets has led to publishing for publishing sake, benefiting the publishers, rather than to advance the cutting-edge of knowledge in any particular field (Buranyi, 2017). This leads, among other things, to questions about the quality and the impact of the journal publications. One of the common indicators to determine the quality relates to citations and impact factor. Clarivate Analytics provides Journal Citation Reports (https://clarivate.com/products/journal-citation-reports/) which can give insight into general trends for citations to a particular journal and the impact a journal has. The impact factor for a journal is calculated by counting all of the citations to every article published in a journal divided by the number of "substantial" articles (original research, long reviews, special communications, etc.) published in that specific journal during the two preceding years (Rhee, 2015). For example, for 2017 The Journal of Manufacturing Technology Management's (http:// emeraldgrouppublishing.com/products/journals/journals.htm?id=jmtm) impact factor was 2.194. A sister journal, The International Journal of Operations and Production Management had an impact factor of 2.955 (http://emeraldgrouppublishing.com/products/journals/journals. $\mathrm{htm}$ ?id=ijopm) while other related journals such as Manufacturing \& Service Operations Management https://pubsonline.informs.org/journal/msom) and Production and Operations Management (https://onlinelibrary.wiley.com/journal/19375956) had impact factors of 1.795 and 1.772, respectively. This type of indicator can be used by schools or groups of schools to provide an indicator of the quality of articles published in journals. For instance, the Australian Business Deans Council publishes a ranking list of journals which includes as one of its criteria the journal citation metrics (https://abdc.edu.au/research/abdc-journal-list/).

Whether citations are a good indicator for quality remains to be seen. A paper can become highly cited because it is good science, or because it is eye-catching, provocative or wrong (Sample, 2013). Also, the question that has been raised is whether citations can be influenced, for example through social media exposure (Tonia et al., 2016). Another issue is the difference between open access vs traditional publishing where readers may need a subscription (Davis et al., 2008). For instance, articles that were deposited in an open access environment received 35 percent more citations on average than non-deposited articles (Davis and Fromerth, 2007). Another complicating factor may be whether a study relates to basic science vs a clinical study (Rhee, 2015). Even the titles of articles may play a role as Jamali and Nikzad (2011) showed that articles with question titles are cited less than other articles. Another important issue is that 25 percent of all citations are perfunctory (Krampen et al., 2007) and thus may not be an indicator of quality or impact.

For business schools, AACSB International, the Association to Advance Collegiate Schools of Business, has a set of standards that includes the issue of impact of the research (AACSB, 2018). Standard 2 indicates "The school produces high-quality intellectual 
JMTM 30,4

652

contributions that are consistent with its mission, expected outcomes, and strategies and that impact the theory, practice, and teaching of business and management." (AACSB, 2018, p. 18) and the list of possible impact indicators includes citation counts (AACSB, 2018, p. 20). However, AACSB recognizes that there are different types of research such as: basic or discovery scholarship, applied or integration/application scholarship, and teaching and learning scholarship (AACSB, 2018). Article downloads are an alternative to citations to determine impact (Pinkowitz, 2002). While citations may be an appropriate indicator for theory oriented journals where scholars read and then cite each other's work, it may be less relevant for practitioner oriented journals where citations are less likely to occur. Article downloads may be a better alternative in such situations which includes JMTM (The Journal of Manufacturing Technology Management). Although JMTM is looking for articles that have a strong theoretical base, it also has a strong emphasis on reality, i.e. research based on empirical data, which therefore informs practitioners on how to improve business.

Citations and downloads are not completely separate. For instance, Pinkowitz (2002) and Watson (2009) showed that downloads are positively correlated with citations while Moed (2005) showed that citations of an article increased the downloading of that article. Shuai et al. (2012) have similar findings related to the publication of preprints, citations and downloads. Furthermore, downloads are correlated with the user base (Davis, 2004). That is, downloads may be dependent upon the number of people that have subscriptions or otherwise read the journal.

What this discussion shows is that impact measures such as citations and downloads are dependent upon the context such as for example the field in which the publications occur as well as the type of publication, etc. Furthermore, for a journal such as JMTM, the article downloads may be a more appropriate indicator for impact than the number of citations. Because of the dependency of the context, this study was initiated to find out what resembles success in terms of publishing in JMTM in the current context. The goal is to provide authors with data-driven analysis that allows the interpretation of how impactful the research is that is published in JMTM. Specifically, the following research question was formulated:

$R Q 1$. What number of downloads is indicative for successful publishing in JMTM?

\section{Methodology}

Rather than analyzing each single paper and the downloading pattern for each paper, a sampling approach was chosen. First, to establish an upper-boundary, the most successful article in terms of downloads was selected. For JMTM, since 2005, the most downloaded article is by Achanga et al. (2006) on critical success factors for lean implementation within SMEs. As of April 2019, this article was downloaded over 31,000 times. The second most downloaded article was downloaded substantially less at 23,000 times (Bhasin and Burcher, 2006). Although published in 2006, by 2019, the Achanga et al. (2006) article is still among the top 4 of the list of articles downloaded in the last 12 months. For example, in the 12-month period prior to April 2019, it was downloaded over 2,000 times with an average of roughly 185 times per month.

Second, with this upper-boundary in place and to provide a context, all other papers that were published in the same issue as the Achanga et al. (2006) article were included in the analysis.

Third, two comparison issues were selected from different timeframes. One issue was selected five years after the issue in which the Achanga et al. (2006) paper was published and at the same time of the year, that is an issue from 2011. Another issue was selected that was published another five years later and again at around the same time of the year, that is an issue from 2016 (although in this instance the issue number was different). 
Fourth, a second comparison issue was selected in 2016. This is because the initial issue in which the Achanga et al. (2006) paper appeared was a special issue. Therefore, a special issue that was published in 2016 was also selected. It should be noted that for this special issue some promotion was done for one of the articles in the special issue based on initial success in terms of downloads for that article (Kothman and Faber, 2016). This promotion occurred to draw attention to the article as well as the special issue and including this also allows insight whether that type of promotion enhances the impact of articles.

All together this means that downloads were analyzed for a total of 29 articles from four issues of JMTM:

- Vol. 17, No. 4;

- Vol. 22, No. 4;

- Vol. 27, No. 3; and

- Vol. 27, No. 7.

For the articles in these four issues of JMTM, two types of analysis were conducted to gain insight into downloading patterns as a proxy for impact and successful publishing in JMTM:

(1) The overall downloads since the article was published.

(2) The immediacy of the impact, measured by looking at the first 12 months after publication.

\section{Data}

\subsection{Total downloads for the life of the article}

Figure 1 shows the total downloads for the articles published in the first issue of JMTM that is under consideration. Since the publication of this issue in April 2006, 13 years have passed, that is 157 months. As explained before, this is a special issue.

In the figure, roughly five groupings can be detected in terms of the number of downloads. That means, the top line in the graph, the second line in the graph, then the

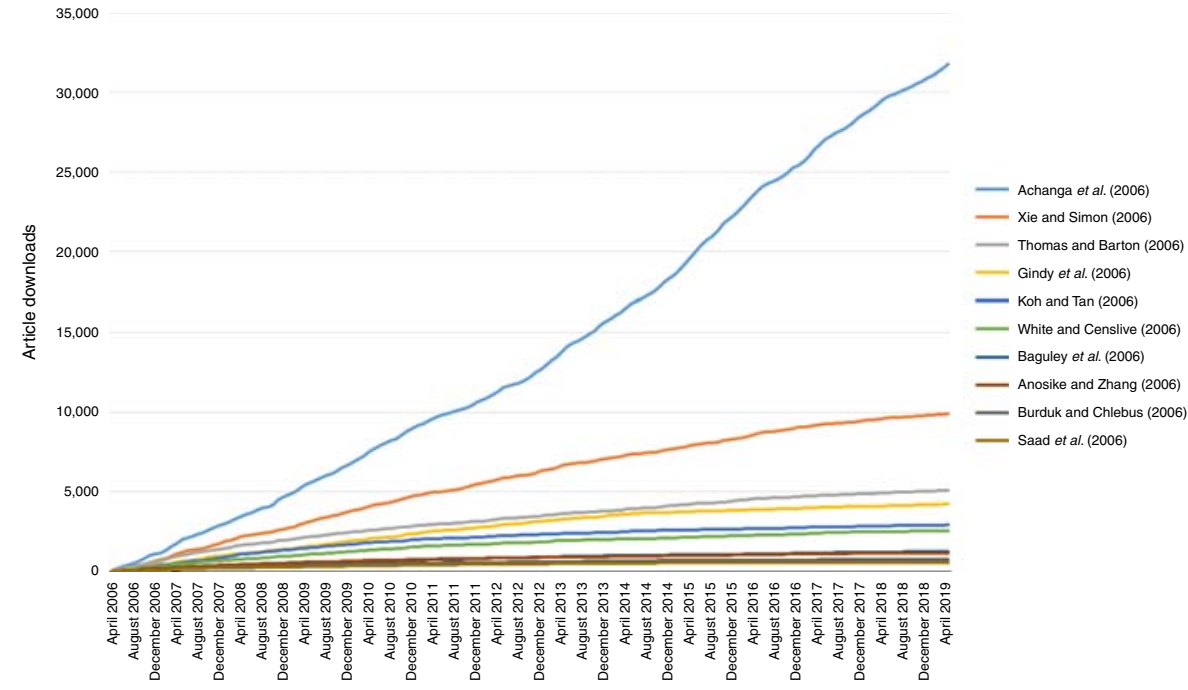

Figure 1. 
JMTM 30,4

654

combination of the third and fourth line in the graph which are close together. The fourth set is the 5th and 6th line in the graph which again appear close together. The last grouping is the group of four articles that are at the bottom of the graph and again, close together.

At the "very high" end is the Achanga et al. (2006) article with almost 32,000 downloads or 204 per month. Next, the Xie and Simon (2006) article can be considered at the "high" level with almost 10,000 downloads or 64 per month. Next, what could be considered "average" are two articles, that is Thomas and Barton (2006) and Gindy et al. (2006), that have around 4,000-5,000 downloads or 25-32 per month. The fourth set of articles can be considered to have a "low" number of downloads. This consists of Koh and Tan (2006) and White and Censlive (2006). These have 2,500-3,000 downloads or 16-19 per month. Last, there is a group of four articles that can be considered to have a "very low" number of downloads. This includes Baguley et al. (2006), Anosike and Zhang (2006), Burduk and Chlebus (2006) and Saad et al. (2006). These articles are roughly in the 500-1,500 download range or 3-10 per month.

Figure 2 shows the total downloads for the articles published in the second issue of JMTM that is under consideration. Since the publication of this issue in April 2011, eight years have passed, that is 97 months. This is a regular issue of JMTM. When comparing Figures 1 and 2, it is noteworthy that whereas most of the papers in Figure 1 seem to have a close to linear pattern of downloads, in Figure 2 most of the papers have a pattern that is more aligned with a logarithmic function. A more linear pattern was also found by Watson (2009) although Pinkowitz (2002) observed a logarithmic pattern with fewer downloads per month the longer a paper is available.

Similar to the previous analysis, roughly five categories of downloads can be distinguished. At the "very high" end is Gurumurthy and Kodali (2011) with 9,000 downloads, that is 93 per month. Next, with "high" downloads is Soon and Udin (2011) with over 6,000 downloads, that is 63 per month. Nobre (2011) and Li (2011) can be considered average with roughly 3,000 downloads, that is 32 per month. The next three article are spread out a bit with Nepal et al. (2011) falling a bit in between Graisa and Al-Habaibeh (2011) and Lin et al. (2011). Considering the previous insights, Graisa and Al-Habaibeh (2011) and Nepal et al. (2011) can be grouped for the "low" number of downloads. These articles have around 1,300-2,000 download or 13-20 per month. The remaining article (Lin et al., 2011) with almost 750 downloads, that is below 10 per month, can be considered to have "very low" downloads.

Figure 2.

Total downloads for Vol. 22, No. 4

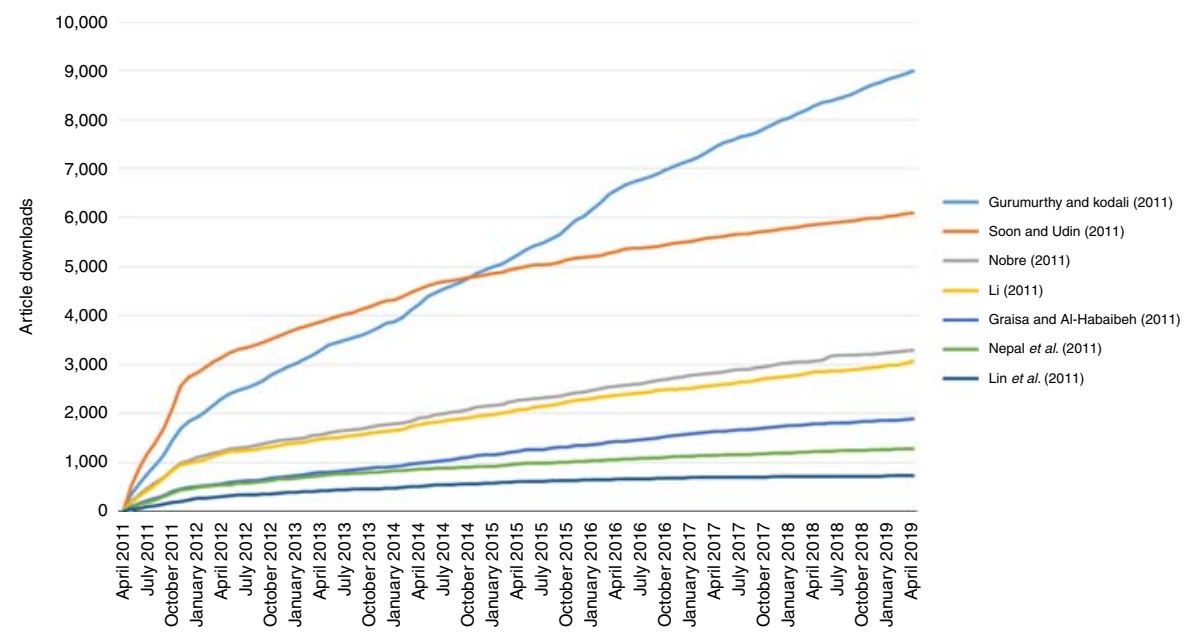


Figure 3 shows the total downloads for the articles published in the third issue of JMTM that is under consideration, i.e. Vol. 27, No. 3. Since the publication of this issue in February 2016, roughly three years have passed, that is 39 months. This is a regular issue of JMTM. In this issue, the download pattern of Piya et al. (2016) seems a bit uncommon. It appears rather bumpy and in April 2018 there is a significant increase in downloads for this paper.

Because this issue only contained six papers, it is not so clear whether the five categories in terms of number of downloads as discussed for the two previous issues also apply here. However, in light of the previously reported number of downloads it appears that for this issue of JMTM, one paper falls inside the "high" download category. This is Srinivasan et al. (2016) with almost 2,300 downloads or about 60 per month. Piya et al. (2016) and Prasad et al. (2016) show an "average" download pattern with, respectively, 1,550 and 1,200 downloads or about 30-40 per month. Bargshady et al. (2016) with almost 875 downloads and E1 Mokadem (2016) with a bit over 700 downloads can be considered "low" in terms of downloads. These represent roughly 20 downloads per month. Mishra et al. (2016) is on the bottom with less than 500 downloads since the article was published, that is 12 per month.

Figure 4 shows the total downloads for the articles published in the last issue of JMTM that is under consideration, i.e. Vol. 27, No. 7. Similar to the first issue that was analyzed, i.e. Vol. 17, No. 4, this was also a special issue. Since the publication of this issue in October 2016 , roughly 2.5 years have passed, that is 31 months. What is noticeable for this special issue is that initially several of the papers seem to have higher downloads and then move to a more linear pattern. This may be due to promotion of this special issue which took place around the late spring in 2017. In particular, the article of Kothman and Faber (2016) was promoted since that was the leading article at that time in terms of downloads. While there does not appear to be a specific effect on Kothman and Faber (2016), it may have drawn attention to other articles in the special issue. Similar to Piya et al. (2016), Rylands et al. (2016) have a step-change around the summer of 2017.

Similar to Vol. 27, No. 3, this issue only contained six papers and so the analysis of the downloads is again viewed in light of Vol. 17, No. 4 and Vol. 22, No. 4. Based on this, Kothman and Faber (2016) can be considered to experience "very high" downloads with 3,100 in total or roughly 100 per month. Oettmeier and Hofmann (2016) falls a bit between the "very high" and "high" categories. The total downloads is almost 2,600 or 84 per month. This is a bit below the

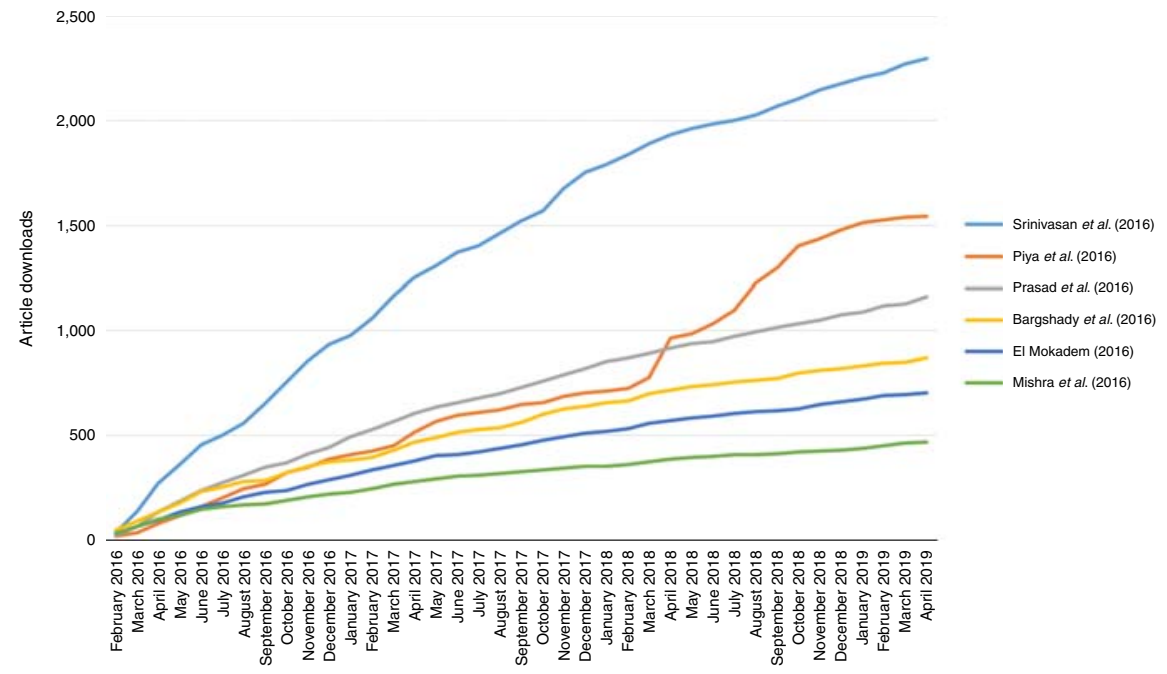

Figure 3. Total downloads for Vol. 27, No. 3 


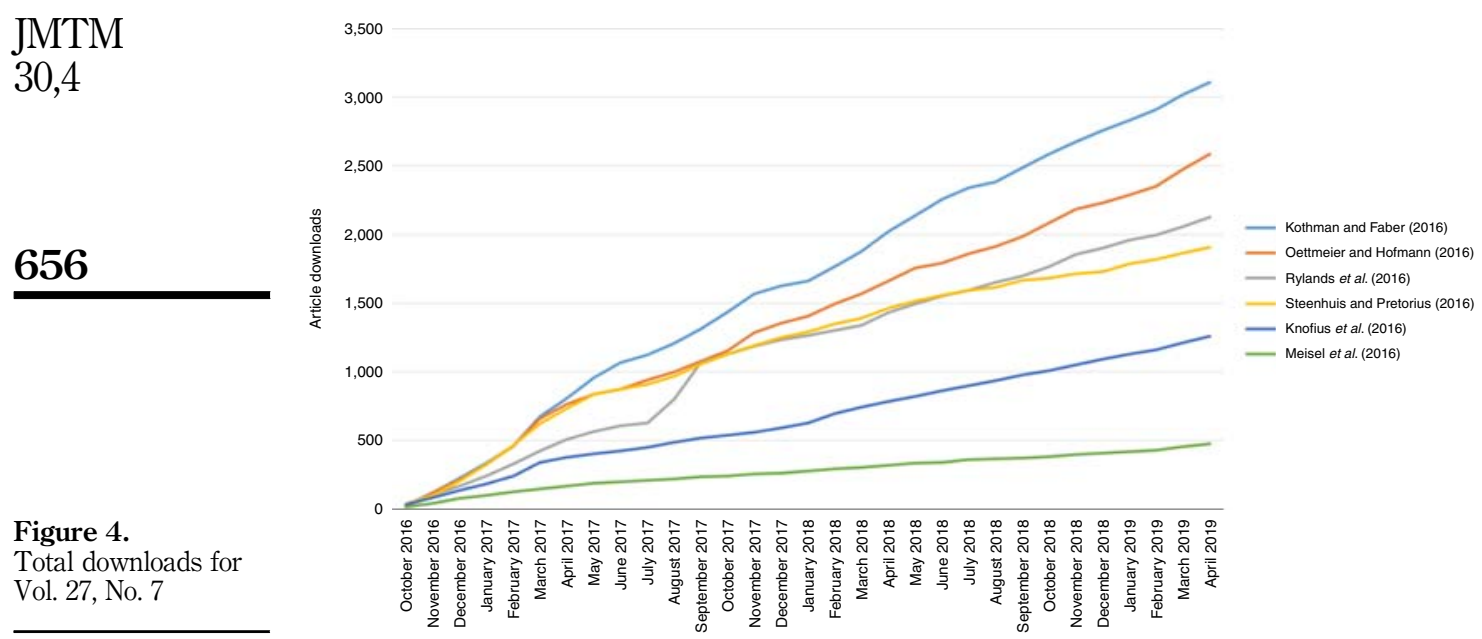

90 per month witnessed in Vol. 22, No. 4 but above the 60-65 from the "high" category. Rylands et al. (2016) and Steenhuis and Pretorius (2016) have around 1,900-2,100 downloads, that is roughly 61-69 per month and can therefore be considered in the "high" download category. Knofius et al. (2016) is a bit lower, that is 1,260 downloads or roughly 40 per month. This can be considered at the high end of the "average" download category. Meisel et al. (2016) is a bit lower again from Knofius et al. (2016) and can be considered as having "low" to "very low" downloads. The total downloads is 480 or roughly 15 downloads per month.

Comparing Figures 3 and 4 shows that while the regular issue has some papers with fewer downloads, the special issue has articles that have higher downloads and/or are at the high end of a particular category of downloads. This is, of course, something that is desired for special issues as it is supposed to attract the attention of the scientific community.

Combining the insights of the analysis of the number of downloads for the 29 articles from publication until April 2019 leads to Tables I and II, which show the five categories of downloads that were found and which of the total set of 29 articles fits into which category. Note that the Achanga et al. (2006) article is a bit of an anamoly for JMTM as its impact and downloads are quite a bit higher than other articles even those that are considered to have a very high number of downloads.

Tables I and II provide an indication of success for authors of articles that have been published in JMTM for the last 10+ years to determine the impact these articles have had in terms of the number of downloads. While journals can change, for instance, JMTM was accepted into the Clarivate Analytics Science Citation Index Expanded and Social Science Citation Index in 2018, which might have an impact on downloads, Table I nevertheless can give some indication for authors of new submissions or recently published articles about what to expect in terms of downloads.

\begin{tabular}{lccccl}
\hline & Vol. 17, No. 4 & Vol. 22, No. 4 & Vol. 27, No. 3 & Vol. 27, No. 7 & Overall per month \\
\hline Very high & $>200$ & \pm 90 & & $>84$ & Roughly 80 and above \\
High & 64 & \pm 60 & 60 & $61-69$ & Roughly 60-70 \\
Average & $25-32$ & \pm 30 & $30-40$ & 40 & Roughly 25-45 \\
Low & $16-19$ & $13-20$ & 20 & 15 & Roughly 15-20 \\
Very low & $3-10$ & 8 & 12 & & Roughly 10 or below
\end{tabular}

Table I.

Cross-issue analysis of average monthly downloads

Very low 


\begin{tabular}{|c|c|c|c|c|c|c|}
\hline & Vol. 17, No. 4 & Vol. 22, No. 4 & Vol. 27 , No. 3 & Vol. 27, No. 7 & Percentage & \\
\hline $\begin{array}{l}\text { Very high } \\
(>80)\end{array}$ & Achanga et al. & $\begin{array}{l}\text { Gurumurthy } \\
\text { and Kodali }\end{array}$ & & $\begin{array}{l}\text { Kothman and Faber } \\
\text { Oettmeier and } \\
\text { Hofmann }\end{array}$ & 14 & \\
\hline High (60-70) & Xie and Simon & Soon and Udin & $\begin{array}{l}\text { Srinivasan } \\
\text { et al. }\end{array}$ & $\begin{array}{l}\text { Rylands } \text { et al. } \\
\text { Steenhuis and } \\
\text { Pretorius }\end{array}$ & 17 & 657 \\
\hline Average (25-45) & $\begin{array}{l}\text { Thomas and Barton } \\
\text { Gindy et al. }\end{array}$ & $\begin{array}{l}\text { Nobre } \\
\text { Lin }\end{array}$ & $\begin{array}{l}\text { Piya et al. } \\
\text { Prasad et al. }\end{array}$ & Knofius et al. & 24 & \\
\hline Low (15-20) & $\begin{array}{l}\text { Koh and Tan } \\
\text { White and Censlive }\end{array}$ & $\begin{array}{l}\text { Graisa and } \\
\text { Al-Habaibeh } \\
\text { Nepal } \text { et al. }\end{array}$ & $\begin{array}{l}\text { Bargshady } \\
\text { et al. } \\
\text { El Mokadem }\end{array}$ & Meisel et al. & 24 & Table II \\
\hline Very low $(<10)$ & $\begin{array}{l}\text { Baguley et al. } \\
\text { Anosike and Zhang } \\
\text { Burduk and Chlebus } \\
\text { Saad } \text { et al. }\end{array}$ & Lin et al. & Mishra et al. & & 21 & $\begin{array}{r}\text { Summary } \\
\text { classification and } \\
\text { distribution of } \\
\text { analyzed articles }\end{array}$ \\
\hline
\end{tabular}

On the one hand, the number of downloads for $J M T M$ is significantly higher than for example data published for the Journal of Vision as reported by Watson (2009), that is reaching 1,000 downloads in roughly seven years or about 12 downloads per month. However, it is now 2019 so perhaps a repeat of the analysis for the Journal of Vision would show different numbers. On the other hand, the number of downloads for JMTM is significantly lower than for example for the Journal of Finance as reported by Pinkowitz (2002), that is from an average of 85 downloads per paper per month. The difference in numbers of downloads may be due to a variety of factors such as reputation of the journal, different types of disciplines or other factors.

\subsection{Immediacy impact; downloads for the first 12 months}

Figures 5, 6, 7 and 8 shows the immediacy impact of the 29 articles in the four issues of JMTM by looking downloads in the first 12 months of publication. For ease of comparison, the scale for Vol. 17, No, 4, Vol. 27, No. 3 and Vol. 27, No. 7 is set at 1,600 downloads. Vol. 22, No. 4 has some articles with higher downloads so this scale is double, that is 3,200 downloads.

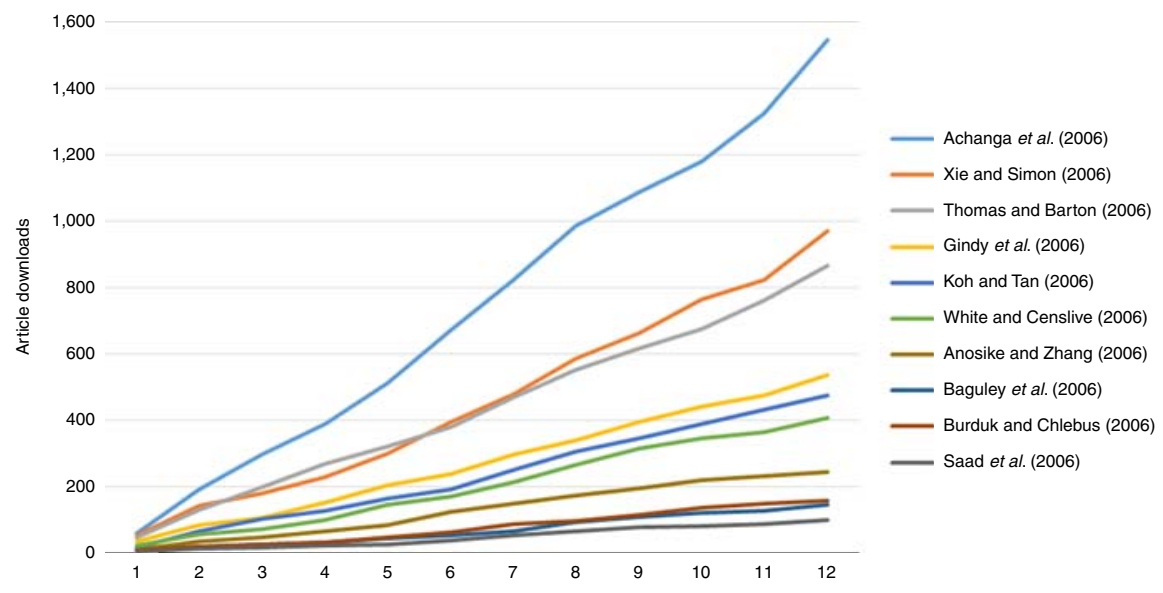

Figure 5.

Downloads during the first 12 months for Vol. 17, No. 4 
JMTM

30,4

658

Figure 6.

Downloads during the first 12 months for Vol. 22, No. 4

Figure 7.

Downloads during the first 12 months for Vol. 27, No. 3

Figure 8.

Downloads during the first 12 months for Vol. 27, No. 7
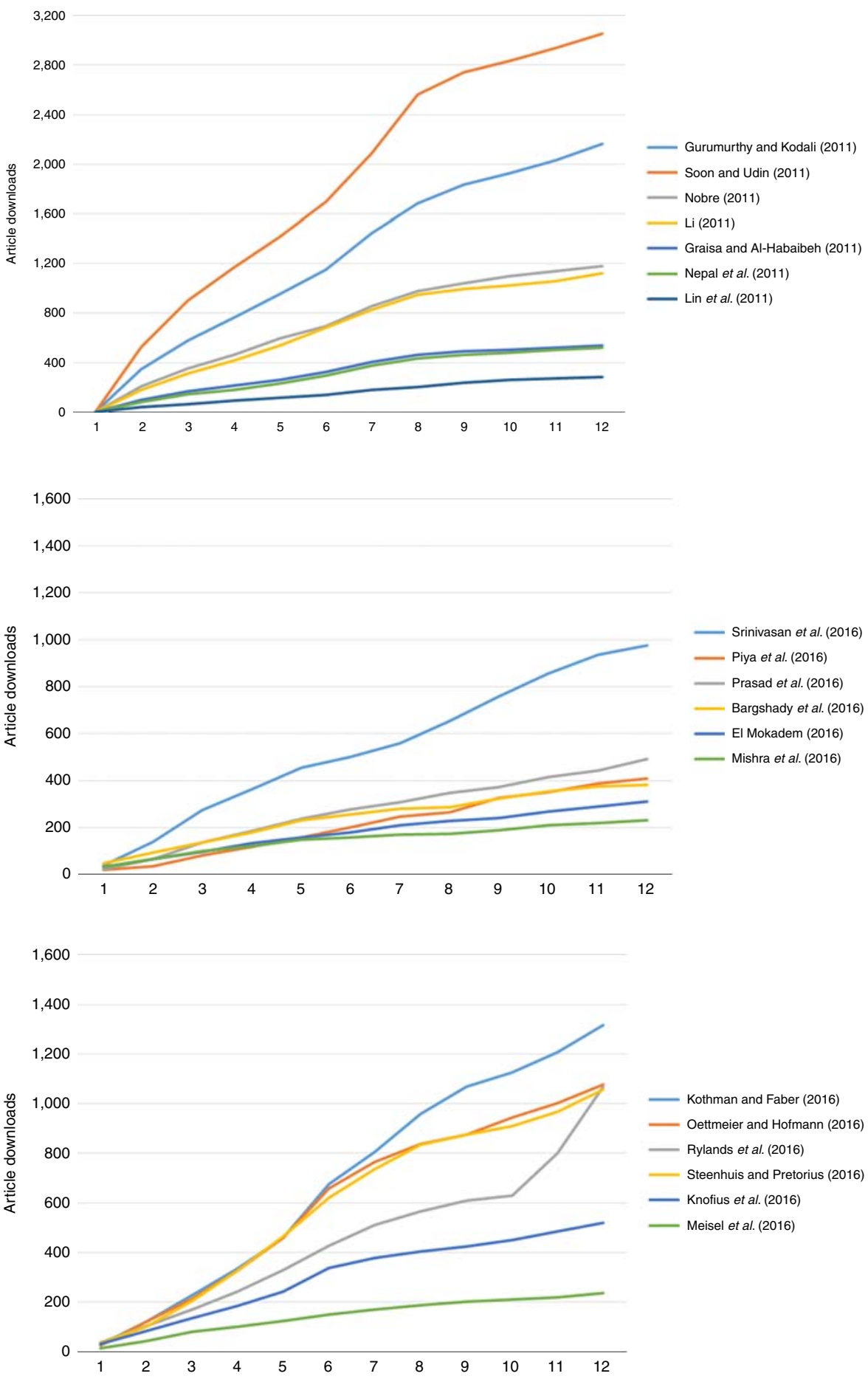
A first observation is that Vol. 22, No. 4 has high downloads during the first year. Four of the articles are around 1,200 downloads or more. For the other three issues, only two other articles reach that number, that is Achanga et al. (2006) and Kothman and Faber (2016). This is a bit unusual, especially since Table II shows that no article has a very high pattern of download for the life of the article and only one article has a high pattern of downloads. The explanation for this is that, as noted above in the discussion of Figure 2, the articles in Vol. 22 , No. 4 show a logarithmic pattern. This means a high number of downloads initially, but then the number of downloads per month slows down.

Second, and similar to the analysis of the total downloads of articles over their lifetime, when starting with Figure 5, that is Vol. 17 No. 4, five groupings of downloads can be distinguished. At the "very high" end is Achanga et al. (2006), at the "high" end are Xie and Simon (2006) and Thomas and Barton (2006), at the "average" level of downloads for the first 12 months is the group of three articles, that is Gindy et al. (2006), Koh and Tan (2006) and White and Censlive (2006). Anosike and Zhang (2006) is a little below that and can be considered "low" in terms of the 12-month downloads whereas the bottom three articles in Figure 5 can be considered "very low", that is Baguley et al. (2006), Burduk and Chlebus (2006) and Saad et al. (2006). When comparing this division or grouping with Figures 7 and 8, it leads to the following categories for the first 12-month downloads: "very low" roughly 150 or fewer downloads or less than 13 per month, "low" up to roughly 250 downloads or up to roughly 20 per month, and "average" in the range of 300-550 downloads or up to roughly 45 per month., "High" could be seen in the range of 800-1,000 downloads which is in the range of 67-83 per month which is a bit higher than what was proposed in Table I. Adjusting slightly down to papers of up to about 850 downloads brings it down to a similar category as in Table I, that is up to about 70 downloads per month. The "very high" group would then be for 1,000 or higher downloads which is roughly 80 per month if adjusted slightly downward to about 960 downloads in the first year. This categorization roughly equates with Table I and based on this Table III was created with the classification of papers, including Vol. 22, No. 4. The table contains the rough groupings for downloads for the first year and between brackets how this equates per month.

\begin{tabular}{|c|c|c|c|c|c|}
\hline & Vol. 17, No. 4 & Vol. 22 , No. 4 & Vol. 27, No. 3 & Vol. 27, No. 7 & Percentage \\
\hline $\begin{array}{l}\text { Very } \\
\text { high } \\
>960 \\
(>80)\end{array}$ & $\begin{array}{l}\text { Achanga et al. } \\
\text { Xie and Simon }\end{array}$ & $\begin{array}{l}\text { Gurumurthy and } \\
\text { Kodali } \\
\text { Soon and Udin } \\
\text { Nobre } \\
\text { Li }\end{array}$ & Srinivasan et al. & $\begin{array}{l}\text { Kothman and Faber } \\
\text { Oettmeier and } \\
\text { Hofmann } \\
\text { Rylands } \text { et al. } \\
\text { Steenhuis and } \\
\text { Pretorius }\end{array}$ & 38 \\
\hline $\begin{array}{l}\text { High } \\
700-850 \\
(60-70)\end{array}$ & Thomas and Barton & & & & 3 \\
\hline $\begin{array}{l}\text { Average } \\
400-550 \\
(25-45)\end{array}$ & $\begin{array}{l}\text { Gindy et al. } \\
\text { Koh and Tan } \\
\text { White and Censlive }\end{array}$ & $\begin{array}{l}\text { Graisa and } \\
\text { Al-Habaibeh } \\
\text { Nepal et al. }\end{array}$ & $\begin{array}{l}\text { Piya et al. } \\
\text { Prasad et al. } \\
\text { Bargshady et al. } \\
\text { El Mokadem }\end{array}$ & Knofius et al. & 34 \\
\hline $\begin{array}{l}\text { Low } \\
170-250 \\
(15-20)\end{array}$ & Anosike and Zhang & Lin et al. & Mishra et al. & Meisel et al. & 14 \\
\hline $\begin{array}{l}\text { Very low } \\
<150 \\
(<12.5)\end{array}$ & $\begin{array}{l}\text { Baguley et al. } \\
\text { Burduk and Chlebus } \\
\text { Saad et al. }\end{array}$ & & & & 10 \\
\hline
\end{tabular}


JMTM 30,4

\section{0}

\subsection{Comparing immediacy and lifetime downloads}

Tables II and III are based on roughly the same number of downloads per month. Table IV provides a comparison for how articles were classified for the life of the article until April 2019, that is Table II, and the immediacy, that is, the classification of downloads for the first 12 months from Table III. Table IV includes only those articles that were classified differently in Tables II and III.

Table IV shows that 18 out of the 29 papers received a higher classification for the immediacy compared to the life of the article. This indicates that initial downloads are higher but that there is a drop-off effect. This was already discussed above for Vol. 22, No. 4 where multiple papers show a pattern that is similar to a logarithmic pattern. Note for instance the strong drop-offs for Nobre (2011) and Li (2011) in Figure 2 which explains the different ratings of "average" for the life of the article vs "very high" in the first 12 months. For the other articles, Figures 1 through 4 do not always show a strong logarithmic pattern but in some instances a difference in the slope can be observed.

\subsection{Title analysis}

As discussed in Section 2, Sample (2013) noted that papers can become highly cited because it is good science, or because it is eye-catching, provocative or wrong. Furthermore, Jamali and Nikzad (2011) showed that titles of articles can play a role for downloads. Therefore, some title analysis were conducted using the five impact categories as identified above and articles that have been published a longer time ago, that is more than five years thus from Vol. 17, No. 4 and Vol. 22, No. 4, see Table V.

Based on Table V, it seems that general topics related to manufacturing and dealing with "how" to do something score average. The articles that have low or very low downloads seem to be either "mathematical" (such as optimization, algorithms, simulation and modeling) or related to specific circumstances which may lack broader appeal (such as the biomedical case, Libya situation). For the "mathematical" articles, this is understandable as

\begin{tabular}{|c|c|c|c|c|c|c|}
\hline & & \multicolumn{5}{|c|}{ Download category for life of the article } \\
\hline & & Very low & Low & Average & High & Very high \\
\hline \multirow{5}{*}{$\begin{array}{l}\text { Download } \\
\text { category } \\
\text { for } \\
\text { immediacy }\end{array}$} & Very low & & & & & \\
\hline & Low & $\begin{array}{l}\text { Anosike and } \\
\text { Zhang } \\
\text { Lin et al. } \\
\text { Mishra et al. }\end{array}$ & & & & \\
\hline & Average & & $\begin{array}{l}\text { Koh and Tan } \\
\text { White and } \\
\text { Censlive } \\
\text { Graisa and } \\
\text { Al-Habaibeh } \\
\text { Nepal } \text { et al. } \\
\text { Bargshady } \\
\text { et al. } \\
\text { El Mokadem }\end{array}$ & & & \\
\hline & High & & & $\begin{array}{l}\text { Thomas and } \\
\text { Barton }\end{array}$ & & \\
\hline & Very high & & & $\begin{array}{l}\text { Nobre } \\
\mathrm{Li}\end{array}$ & $\begin{array}{l}\text { Xie and } \\
\text { Simon } \\
\text { Soon and } \\
\text { Udin } \\
\text { Srinivasan } \\
\text { et al. } \\
\text { Rylands et al. } \\
\text { Steenhuis } \\
\text { and Pretorius }\end{array}$ & \\
\hline
\end{tabular}

Table IV.

Comparison of immediacy with life of article download pattern 
Download

Authors

Very low Taboo search vs generic algorithms in solving and optimizing PCB Saad et al. (2006) problems

Variant simulation in design and risk estimation of manufacturing Burduk and Chlebus system (2006)

Dynamic reconfiguration and simulation of manufacturing systems Anosike and Zhang using agents

Time to market prediction using Type-2 fuzzy sets

(2006)

Using grey relational analysis and TRIZ to identify KSFs and Lin et al. (2011)

strategies for choosing importers and exporters: an example of the Taiwanese hand-tool industry

Low

Translating knowledge of supply chain uncertainty into business strategy and actions

Observations on modeling strategies for vendor-managed inventory

Koh and Tan (2006)

White and Censlive (2006)

Improving manufacturing process for biomedical products: a case Nepal et al. (2011) study

An investigation into current production challenges facing the

Graisa and Libyan cement industry and the need for innovative total

Al-Habaibeh (2011) productive maintenance (TPM) strategy

Average

Technology roadmapping for the next generation manufacturing enterprise

Developing an SME based six sigma strategy

Gindy et al. (2006)

Thomas and Barton (2006)

ERP adoption in Chinese small enterprise: an exploratory case study Li (2011)

Core competencies of the new industrial organization

Nobre (2011)

High Simulation for product life cycle management

Xie and Simon (2006)

Supply chain management from the perspective of value chain Soon and Udin flexibility: an exploratory study

Very high

Critical success factors for lean

(2011)

Achanga et al. (2006)

Design of lean manufacturing systems using value stream mapping Gurumurthy and with simulation: a case study

Kodali (2011)

Table V. Analysis of article titles and download pattern

this is not aligned well with the JMTM readership. Furthermore, there are several journals available that have a strong focus on those types of papers and readers are more likely to go to those journals if they are interested in those types of studies.

For the specific circumstances that are indicated in a title, this may make a paper less appealing as the applicability of studies outside of those circumstances may be low and hence they may attract fewer readers. In recent years, the editorial office has paid more attention to this aspect as in particular it relates to the overall contribution and theoretical underpinnings of studies. Studies that are too narrowly focused on specific circumstances are of little help to managers and academics since these circumstances may not appear elsewhere. Therefore, JMTM has increased its attention to this part and is now specifically looking for discussion sections that discuss how the specific context of a study relates to the broader business context and conditions. This means that the editorial office is expecting a discussion section, typically after the data and findings of a study, which explicitly connects back to the literature review and where the study's findings are compared and contrasted with previous findings from other studies and perhaps under different circumstances. This type of discussion elevates an article from the specific context into a more general context with a broader understanding of the variables and theoretical underpinnings that play a role. This helps to raise the contribution of the paper. The value, therefore, is no longer the specific context but rather what can be 
JMTM 30,4

662

learned from different types of contexts and how this aids the forming of new theory and/or providing practical insight into contextual variables so that it becomes meaningful for managers.

The high or very high download articles seem to be related to general manufacturing related topics which are of high interest such as supply chain management or lean, and may have benefited from good timing as well as adding new insights.

\section{Conclusion}

The purpose of this study was to provide authors of articles that are published in JMTM with insight into what can be considered successful publishing in JMTM. To that end, an analysis was conducted on the number of downloads of articles for a sample of 29 articles that were published across four issues of JMTM. The number of downloads was considered a proxy for the impact of publishing an article in JMTM. It led to a classification scheme that varies from a very low number of downloads at roughly 10 or fewer per month to a very high number of downloads at roughly 80 or more downloads per month. Some articles, such as the very successful Achanga et al. (2006) publication with an average of over 200 downloads per month achieve considerably more. Authors of publications in JMTM can see download information on the journal's webpage (https://emeraldinsight.com/loi/jmtm) and based on this can get an idea how successful their publication is in terms of downloads compared to the classification scheme of other articles that have been published in JMTM.

Some additional analysis were conducted that showed that in many instances, articles initially do well and then move to a more or less linear pattern of downloads although some instances of a logarithmic pattern were also observed. This is similar to what was found in the literature. Download patterns are further context dependent and thus finding should be treated with some caution as circumstances and reputation of a journal might for example change. Additionally, analysis of titles were conducted which provided additional insight into areas that can lead to higher download patterns.

It should be noted that high downloads is not equivalent with high quality. It is very well possible to have a very high-quality study but that does not appear to be downloaded a lot. This can be because the paper appears in a niche area. JMTM remains committed to publishing high-quality papers and, therefore, high-quality papers, but with limited download or citation potential, are not automatically disregarded.

For future research it would be interesting to repeat this type of study in 5 or 10 years to see if the classification scheme remains valid or whether it needs to be adjusted. It would also be interesting to have comparisons with other journals to determine how the download classification for JMTM compares with other journals. Furthermore, this could lead to additional insight into journal-dependent factors that can influence downloading patterns.

\section{Harm-Jan Steenhuis}

\section{References}

AACSB (2018), "2013 eligibility procedures and accreditation standards for business accreditation”, available at: www.aacsb.edu/accreditation/standards/business (accessed April 28, 2019).

Achanga, P., Shehab, E., Roy, R. and Nelder, G. (2006), "Critical success factors for lean implementation within SMEs", Journal of Manufacturing Technology Management, Vol. 17 No. 4, pp. 460-471.

Anosike, A.I. and Zhang, D.Z. (2006), "Dynamic reconfiguration and simulation of manufacturing systems using agents", Journal of Manufacturing Technology Management, Vol. 17 No. 4, pp. 435-447.

Baguley, P., Page, T., Koliza, V. and Maropoulos, P. (2006), “Time to market prediction using type-2 fuzzy sets", Journal of Manufacturing Technology Management, Vol. 17 No. 4, pp. 513-520. 
Bargshady, G., Zahraee, S.M., Ahmadi, M. and Parto, A. (2016), "The effect of information technology on the agility of the supply chain in the Iranian power plant industry", Journal of Manufacturing Technology Management, Vol. 27 No. 3, pp. 427-442.

Belcher, W.L. (2009), Writing Your Journal Article in Twelve Weeks: A Guide to Academic Publishing Success, SAGE Publications, Thousand Oaks, CA.

Bhasin, S. and Burcher, P. (2006), "Lean viewed as a philosophy", Journal of Manufacturing Technology Management, Vol. 17 No. 1, pp. 56-72.

Bloomberg, L.D. and Volpe, M. (2019), Completing Your Qualitative Dissertation: A Road Map From Beginning to End, SAGE Publications, Thousand Oaks, CA.

Brown, P.R. (2013), "How can we do better", Accounting Horizons, Vol. 27 No. 4, pp. 855-859.

Buranyi, S. (2017), "Is the staggeringly profitable business of scientific publishing bad for science?", available at: www.theguardian.com/science/2017/jun/27/profitable-business-scientificpublishing-bad-for-science (accessed April 29, 2019).

Burduk, A. and Chlebus, E. (2006), "Variant simulation in design and risk estimation of manufacturing system”, Journal of Manufacturing Technology Management, Vol. 17 No. 4, pp. 448-459.

Chrisman, J.J., Sharma, P. and Chua, J. (2017), "The mind-set of editors and reviewers”, Family Business Review, Vol. 30 No. 3, pp. 211-218.

Claudio, L. and Boles, J. (2016), How to Write and Publish a Scientific Paper: The Step by Step Guide, Write Science Now Publishing Company, New York, NY.

Dalton, D.W., Harp, N.L., Oler, D.K. and Widener, S.K. (2016), "Managing the review process in accounting research: advice from authors and editors", Issues in Accounting Education, Vol. 31 No. 2, pp. 235-252.

Davis, P.M. (2004), "For electronic journals, total downloads can predict number of users", portal: Libraries and the Academy, Vol. 4 No. 3, pp. 379-392.

Davis, P.M. and Fromerth, M.J. (2007), "Does the arXiv lead to higher citations and reduced publisher downloads for mathematics articles?", Scientometrics, Vol. 71 No. 2, pp. 203-215.

Davis, P.M., Lewenstein, B.V., Simon, D.H., Booth, J.G. and Connolly, M.J.L. (2008), "Open access publishing, article downloads, and citations: randomized controlled trial", available at: www. bmj.com/content/337/bmj.a568.short (accessed April 26, 2019).

El Mokadem, M. (2016), "ISO 9000 moderating role over supply chain alignment in manufacturing context”, Journal of Manufacturing Technology Management, Vol. 27 No. 3, pp. 338-363.

Gans, J.S. and Shepherd, G.B. (1994), "How are the mighty fallen: rejected classic articles by leading economists", Journal of Economic Perspectives, Vol. 8 No. 1, pp. 165-179.

Gindy, N.N.Z., Cerit, B. and Hodgson, A. (2006), "Technology roadmapping for the next generation manufacturing enterprise", Journal of Manufacturing Technology Management, Vol. 17 No. 4, pp. 404-416.

Graisa, M. and Al-Habaibeh, A. (2011), "An investigation into current production challenges facing the Libyan cement industry and the need for innovative total productive maintenance (TPM) strategy”, Journal of Manufacturing Technology Management, Vol. 22 No. 4, pp. 541-558.

Gurumurthy, A. and Kodali, R. (2011), "Design of lean manufacturing systems using value stream mapping with simulation: a case study", Journal of Manufacturing Technology Management, Vol. 22 No. 4, pp. 444-473.

Gutman, S.A. (2017), Journal Article Writing and Publication: Your Guide to Mastering Clinical Health Care Reporting Standards, SLACK Incorporated, Thorofare, NJ.

Jamali, H.R. and Nikzad, M. (2011), "Article title type and its relation with the number of downloads and citations”, Scientometrics, Vol. 88 No. 2, pp. 653-661.

Kachewar, S.G. and Sankaye, S.B. (2013), "Reviewer index: a new proposal of rewarding the reviewer", Mens Sana Monographs, Vol. 11 No. 1, pp. 274-284. 
JMTM 30,4

Knofius, N., van der Heijden, M.C. and Zijm, W.H.M. (2016), "Selecting parts for additive manufacturing in service logistics", Journal of Manufacturing Technology Management, Vol. 27 No. 7, pp. 915-931.

Koh, S.C.L. and Tan, K.H. (2006), "Translating knowledge of supply chain uncertainty into business strategy and actions", Journal of Manufacturing Technology Management, Vol. 17 No. 4, pp. $472-485$.

Kothman, I. and Faber, N. (2016), "How 3D printing technology changes the rules of the game: insights from the construction sector", Journal of Manufacturing Technology Management, Vol. 27 No. 7 , pp. 932-943.

Krampen, G., Becker, R., Wahner, U. and Montada, L. (2007), "On the validity of citation counting in science evaluation: content analysis of references and citations in psychological publications", Scientometrics, Vol. 71 No. 2, pp. 191-202.

Larsen, P.O. and von Ins, M. (2010), "The rate of growth in scientific publication and the decline in coverage by Science Citation Index", Scientometrics, Vol. 84 No. 3, pp. 575-603.

Li, Y. (2011), "ERP adoption in Chinese small enterprise: an exploratory case study", Journal of Manufacturing Technology Management, Vol. 22 No. 4, pp. 489-505.

Lin, P.Y., Lee, T.R. and Dadura, A.M. (2011), "Using grey relational analysis and TRIZ to identify KSFs and strategies for choosing importers and exporters: an example of the Taiwanese hand-tool industry”, Journal of Manufacturing Technology Management, Vol. 22 No. 4, pp. 474-488.

Liu, L.A. (2014), “Addressing reviewer comments as an integrative negotiation”, Management and Organization Review, Vol. 10 No. 2, pp. 183-190.

Lunenburg, F.C. and Irby, B.J. (2008), Writing a Successful Thesis or Dissertation: Tips and Strategies for Students in the Social and Behavioral Sciences, Corwin Press, Thousand Oaks, CA.

MacDonald, F. (2016), "8 Scientific papers that were rejected before going on to win a Nobel prize", available at: www.sciencealert.com/these-8-papers-were-rejected-before-going-on-to-win-thenobel-prize (accessed April 28, 2019).

Meisel, N.A., Williams, C.B., Ellis, K.P. and Taylor, D. (2016), "Decision support for additive manufacturing deployment in remote or austere environments", Journal of Manufacturing Technology Management, Vol. 27 No. 7, pp. 898-914.

Mishra, R., Pundir, A.K. and Ganapathy, L. (2016), "Conceptualizing sources, key concerns and critical factors for manufacturing flexibility adoption: an exploratory study in Indian manufacturing firms”, Journal of Manufacturing Technology Management, Vol. 27 No. 3, pp. 379-407.

Moed, H.F. (2005), "Statistical relationships between downloads and citations at the level of individual documents within a single journal", Journal of the American Society for Information Science and Technology, Vol. 56 No. 10, pp. 1088-1097.

Nepal, B., Natarajarathinam, M. and Balla, K. (2011), "Improving manufacturing process for biomedical products: a case study”, Journal of Manufacturing Technology Management, Vol. 22 No. 4, pp. 527-540.

Nobre, F.S. (2011), "Core competencies of the new industrial organization", Journal of Manufacturing Technology Management, Vol. 22 No. 4, pp. 422-443.

Oettmeier, K. and Hofmann, E. (2016), "Impact of additive manufacturing technology adoption on supply chain management processes and components", Journal of Manufacturing Technology Management, Vol. 27 No. 7, pp. 944-968.

Pinkowitz, L. (2002), "Research dissemination and impact: evidence from web site downloads", The Journal of Finance, Vol. LVII No. 1, pp. 485-499.

Piya, S., Khadem, M.M.R.K. and Shamsuzzoha, A. (2016), "Negotiation based decision support system for order acceptance”, Journal of Manufacturing Technology Management, Vol. 27 No. 3, pp. 443-468.

Prasad, S., Khanduja, D. and Sharma, S.K. (2016), "An empirical study on applicability of lean and green practices in the foundry industry", Journal of Manufacturing Technology Management, Vol. 27 No. 3, pp. 408-426. 
Rhee, J.S. (2015), "High-impact articles - citations, downloads, and altmetric score", JAMA Facial Plastic Surgery, Vol. 17 No. 5, pp. 323-324.

Rylands, B., Böhme, T., Gorkin, R., Fan, J. and Birtchnell, T. (2016), “The adoption process and impact of additive manufacturing on manufacturing systems", Journal of Manufacturing Technology Management, Vol. 27 No. 7, pp. 969-989.

Saad, S., Khalil, E., Fowkes, C., Basarab-Horwath, I. and Perera, T. (2006), "Taboo search vs genetic algorithms in solving and optimizing PCB problems", Journal of Manufacturing Technology Management, Vol. 17 No. 4, pp. 521-536.

Sample, I. (2013), "Nobel winner declares boycott of top science journals", available at: www.theguardian.com/science/2013/dec/09/nobel-winner-boycott-science-journals (accessed April 28, 2019).

Saunders, C. (2005a), “Looking for diamond cutters”, MIS Quarterly, Vol. 29 No. 1, pp. iii-viii.

Saunders, C. (2005b), "From the trenches: thoughts on developmental reviewing", MIS Quarterly, Vol. 29 No. 2, pp. iii-xii.

Shuai, X., Pepe, A. and Bollen, J. (2012), "How the scientific community reacts to newly submitted preprints: article downloads, twitter mentions, and citations", PLOS one, Vol. 7 No. 11.

Sigelman, L. and Whicker, M.L. (1987), "Some implications of bias in peer review: a simulation-based analysis”, Social Science Quarterly, Vol. 68 No. 3, pp. 494-509.

Silvia, P.J. (2015), Write It Up: Practical Strategies for Writing and Publishing Journal Articles, APA LifeTools, Washington, DC.

Soon, Q.H. and Udin, Z.M. (2011), "Supply chain management from the perspective of value chain flexibility: an exploratory study", Journal of Manufacturing Technology Management, Vol. 22 No. 4, pp. 506-526.

Srinivasan, S., Hughes Ikima, L., Shakouri, M., Nahmens, I. and Harvey, C. (2016), “5S impact on safety climate of manufacturing workers", Journal of Manufacturing Technology Management, Vol. 27 No. 3, pp. 364-378.

Steenhuis, H.J. and Pretorius, L. (2016), "Consumer additive manufacturing or 3D printing adoption: an exploratory study", Journal of Manufacturing Technology Management, Vol. 27 No. 7, pp. 990-1012.

Te'eni, D., Rowe, F., Ågerfal, P.J. and Lee, J.S. (2015), "Publishing and getting published in EJIS: marshalling contributions for a diversity of genres", European Journal of Information Systems, Vol. 24 No. 6, pp. 559-568.

Thomas, A. and Barton, R. (2006), "Developing an SME based six sigma strategy", Journal of Manufacturing Technology Management, Vol. 17 No. 4, pp. 417-434.

Tonia, T., Van Oyen, H., Berger, A., Schindler, C. and Künzli (2016), "If I tweet will you cite? The effect of social media exposure of articles on downloads and citations", International Journal of Public Health, Vol. 61 No. 4, pp. 513-520.

Watson, A.B. (2009), "Comparing citations and downloads for individual articles", Journal of Vision, Vol. 9 No. 4, pp. 1-4.

Weber, R. (1999), "The journal review process: a manifesto for change", Communications of the Association for Information Systems, Vol. 2 No. 1, pp. 2-22, available at: http://aisel.aisnet.org/ cais/vol2/iss $1 / 12$

White, A.S. and Censlive, M. (2006), "Observations on modelling strategies for vendor-managed inventory", Journal of Manufacturing Technology Management, Vol. 17 No. 4, pp. 496-512.

White, G.E. (2017), The Dissertation Warrior: The Ultimate Guide to Being the Kind of Person Who Finishes a Doctoral Dissertation or Thesis, Triumphant Heart International, Happy Valley, OR.

Xie, X. and Simon, M. (2006), "Simulation for product life cycle management", Journal of Manufacturing Technology Management, Vol. 17 No. 4, pp. 486-495. 